\title{
DESTRUCTION OF SOCIAL CAPITAL IN GERMANY IN THE INTERWAR PERIOD - AN AUSTRIAN PERSPECTIVE ON THE DISASTER
}

\author{
PETRA TRÄG*
}

Fecha de recepción: 5 de agosto de 2018

Fecha de aceptación: 30 de septiembre de 2019

Abstract: The accumulated capital of all charitable foundations existing in a country is the financial social capital of this nation. In Germany, the stock of charitable foundations which supports e. g. poor, disabled, ill, the elderly and helpless people has grown to around 100,000 until the beginning of the $20^{\text {th }}$ century. The currency reform in 1923 devaluated most of the social capital. More than $90 \%$ of the charitable foundations were destroyed.

From an Austrian perspective, the article sheds light on how this catastrophe could have happened. Main causes are the money policy and, in particular, state interventions in the foundation's assets. These state interventions and the unintended side-effects are investigated and evaluated from the viewpoints of the Austrian School of Economics. Finally, the long-term effects of the gilt-edged rule for social capital and other capital-collecting agencies such as life insurance companies are examined for the further development of the German economy.

Keywords: social capital, money policy, state interventions, spiral of intervention, charitable foundation, gilt-edged, destruction of foundation's capital.

JEL classification: D64, E14, E31, E40, E65.

Resumen: El capital acumulado de todas las fundaciones caritativas existentes en un país representa su capital social financiero. En Alemania, el número de fundaciones de beneficencia que, por ejemplo, apoyan a personas pobres,

\footnotetext{
* Petra Träg (pm.traeg@arcor.de) is currently a doctoral candidate at the King Juan Carlos University in Madrid, Spain.
} 
discapacitadas, enfermas, ancianas y desamparadas ha crecido hasta alcanzar alrededor de 100.000 hasta principios del siglo xx. La reforma monetaria de 1923 devaluó la mayor parte del capital social. Más del 90\% de las fundaciones caritativas fueron destruidas.

Desde una perspectiva austríaca, el artículo arroja luz sobre cómo pudo haber ocurrido esta catástrofe. Las causas principales son la política monetaria y, en particular, las intervenciones estatales en el patrimonio de las fundaciones. Estas intervenciones estatales y los efectos secundarios no deseados se investigan y evalúan desde el punto de vista de la Escuela Austríaca de Economía. Por último, se examinan a largo plazo los efectos de las normativas con garantía pupilar al capital social y a otras agencias de captación de capital, como las compañías de seguros de vida para el desarrollo posterior de la economía alemana.

Palabras clave: capital social, política monetaria, intervenciones estatales, espiral de intervención, fundación benéfica, garantía de oro, destrucción del capital de la fundación.

Clasificación JEL: D64, E14, E31, E40, E65.

\section{I \\ INTRODUCTION}

Foundations are - as financially independent institutions - the "savings deposits" of a functioning civil society. ${ }^{1}$ The accumulated capital of all charitable foundations existing in a country is the financial social capital of this nation. This social capital was made available from private persons for public welfare. Even today, foundations are an element of a liberal and solidary civil society. ${ }^{2}$ In Germany, the stock of charitable foundations has grown over centuries, starting in 917 with the first officially documented Hospitalstiftung Wemding ${ }^{3}$ which still exists today.

\footnotetext{
1 Cp. Anheier, H. et al. (2004), p. 10.

2 Cp. Kraus, E. (2001), p. 400.

${ }^{3}$ Cp. Anheier, H. (2003), p. 72.
} 
Until the beginning of the industrialization many foundations came into existence which cared for orphans, sick people and the elderly and provided food ${ }^{4}$ for the poor. In the $17^{\text {th }}$ and $18^{\text {th }}$ century the number of foundations for education, study and scholarship increased enormously. ${ }^{5}$

With the industrialization the citizen's savings increased ${ }^{6}$ and some people became very rich. The very increase of wealth has made the economic suffering of the poor people more conspicuous, even though the people were not necessarily worse off than their ancestors. ${ }^{7}$ The discrepancy between capitalism and the misery of the poor part of population caused indignation and the social grievances were declared as the social question of the $19^{\text {th }}$ century. ${ }^{8}$ In Germany, the stock of charitable foundations has grown up to around 100,000 until the beginning of the $20^{\text {th }}$ century and could have reduced the suffering and misery of Germans in the interwar period and could have supported the reconstruction of the economy.

Precisely at this moment, when help was most urgently needed ${ }^{9}$ the state-ordered currency reform devaluated most of the social capital. More than $90 \%$ of the charitable foundations were destroyed.

Until this incident, the German Empire was according to Thomas Adam the undisputed world power in the field of philanthropy..$^{10} \mathrm{He}$ quantified the total assets of all German foundations and ward money before the outbreak of World War I at 50 billion Mark, ${ }^{11}$ slightly above the GDP of 48 billion Mark. ${ }^{12}$ On the other hand, the figures from Bavaria shows that the Bavarian

4 Cp. Kraus, E. (2012).

5 Cp. Kraus, E. (2012).

6 Cp. Hülsmann, J. (2014), p. 217.

7 Cp. Hayek, F. (1954/2003), p. 18.

8 Cp. Leisering, L. (2005), p. 200.

9 Cp. Reichstagsprotokolle (1925), pp. 11381-11407, 366. Sitzung, 15.6.1923, Discussion of the deputies to make a one-time payment to pay pension entitlements to war veterans. A war invalid would have received 420,000 Mark as capitalized claim on June 15, 1923. MP Karsten says that this amount is not even enough to buy a suit.

10 Cp. Adam, T. (2018), n.p.

11 Cp. Adam, T. (2016), p. 227.

12 Cp. Bruckmüller, E. (2004), p. 135. 
Foundation's assets amounted with 1.21 billion Mark ${ }^{13}$ in the year 1910 only to approximately $30 \%$ of the GDP of the Kingdom of Bavaria. ${ }^{14}$ Even if the figures differ, the size of the catastrophe for the German population can be imagined, especially by comparison:

- England's foundation asset (included Wales) ${ }^{15}$ was only $1.4 \%$ of the GDP of England and Wales ${ }^{16}$ in the year 1908

- America's foundation asset ${ }^{17}$ was only $1 \%$ of the US-GDP ${ }^{18}$ in the year 1930

- German's current endowment capital in the amount of 100 billion Euro ${ }^{19}$ is round about 3\% of the GDP of Germany. ${ }^{20}$

Charitable foundations established a self-organization of the civil society ${ }^{21}$ and the voluntary redistribution of social wealth ${ }^{22}$. The growth of autonomous social capital in Germany has always been the government's object of desire, because politicians want to have a say in the redistribution of wealth. In particular against the background that the rulers have recognized the potential power of social benefits ${ }^{23}$ and that autonomous social capital could compete with the state-controlled welfare state. Governmental redistribution generally happens by state intervention in the market. Thus, even the autonomous social capital was not spared from regulation, which ultimately led to the mass destruction of social capital in 1923.

This article analyzes state interventions in the foundations' activities and in the social capital market from the $19^{\text {th }}$ century

13 Cp. Kraus, E. (2012).

14 Cp. Hoffmann, W. et al. (1959).

15 Cp. Adam, T. (2016), p. 227: Foundations assets of England and Wales in 1908: Pound 27.142.228.

16 Cp. Crafts, N. (2004), p. 10: GDP England and Wales: Pound 1.943,2 Mio.

17 Cp. Adam, T. (2016), p. 227: Foundations assets of the USA in 1930: $\$ 850.000 .000$.

18 Cp. Amadeo, K. (2018): US GDP: \$ 92.000.000.000.

19 Cp. Bundesverband Deutscher Stiftungen (2014), p. 25.

20 Cp. Statista (2018).

21 Cp. Kocka, J. (2004), p. 3.

22 Cp. Adloff, F. (2010), p.15.

23 Cp. Bagus, P. et al. (2014), p. 123. 
onwards until 1923 and considers the catastrophe from the perspective of the Austrian School of Economics. It also examines the implications and unintended side-effects and long-term consequences of government interventions up to 1930.

II

\section{WHAT HAPPENED? DESTRUCTION OF SOCIAL CAPITAL}

On November 15, 1923, with the conversion of the German Mark to Rentenmark, after a phase of hyperinflation, all debt securities of the German foundation capital were devaluated at one blow. Only two years later it became clear that most of the social capital was irretrievably wiped out.

The damage was enormous. More than $90 \%$ of the stock of German charitable foundations were destroyed.

GRAPH 1: DEVELOPMENT OF THE STOCK OF FOUNDATIONS IN GERMANY SINCE 917

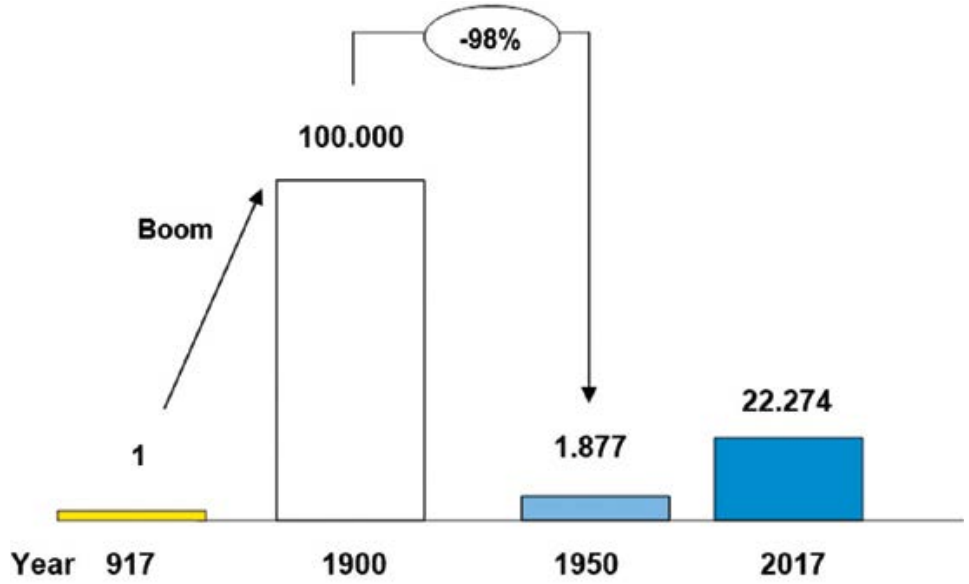

Source: Bundesverband Deutscher Stiftungen 2014 and $2018^{24}$.

${ }^{24}$ Cp. Bundesverband Deutscher Stiftungen (2014), p. 22; p. 49; Bundesverband Deutscher Stiftungen (2018): The number is calculated as the difference between the 
Superficially, hyperinflation is regarded as the cause of this disaster. The currency reform, as the final point of the irresponsible monetary increase, devalued mostly the endowment assets at one stroke on Nov. 15, 1923 and, thus, marginalized the social capital of the Germans. Thus, according to the government's decision, war bonds were devalued to 2.5 percent of the debt. ${ }^{25}$ The Revaluation Act for covered bonds of 1925 was only a confirmation that the state was unwilling to reinstate and revaluate privately earned social capital, which the government has devalued such as all debt securities and money claims and used for debt relief. ${ }^{26}$

According to Elisabeth Kraus a small part of the foundations, which had initially become more or less incapacitated for action, was able to resume its activities towards the end of the 1920s, but this has not reached the level prevalent before World War I and inflation. ${ }^{27}$ Over $90 \%$ of the foundations' stock and its social capital were destroyed, which led to the marginalization of the foundation system. ${ }^{28}$ The effects were not only reflected in the balance sheets of the foundations, but also in the further social development of the population.

III

WHAT LED TO THIS RESULT?

The analysis of the situation showed the most varied interventions that have affected social capital. The range extends from tax burdens or tax relief of social capital $^{29}$ as well as irresponsible

stock of foundations in Germany in 1900 with 100,000 and the number of foundations existing in 1950.

25 Cp. Adam, T. (2015a), p. 213.

${ }^{26}$ Cp. Adam, T. (2018), pp. 15-16.

27 Cp. Kraus, E. (2012).

28 Cp. Strachwitz, R. v. (2017), p. 30.

${ }^{29}$ Until 1905 inheritance tax liability: Former inheritance tax law of Oct. 13,1849, law collection volume VIII, pp. $21 \mathrm{ff}$. As of 1906 inheritance tax exemption for foundations, On April 1,1920 imperial taxes were introduced and income capital pensions and property taxes were abolished in the Länder. In 1933, tax deductibility of donations to charitable foundations was abolished, but worse were the prohibitions and prohibitions on investment and the taxation of the realized capital gain. 
monetary policy and money devaluation to legal regulation and interventions.

According to Mises, an "intervention is an isolated order by the authority in command of the social power apparatus" 30 which compels the owners to use their economic goods in another way as they normally intended. ${ }^{31}$ Interventionism is, therefore, a third system $^{32}$ (between free-market economy and socialism) in which private property is regulated by official interventions by a coercive apparatus. ${ }^{33}$

Mises was convinced that "Mankind has a choice only between the unhampered market economy, democracy, and freedom on the one side, and socialism and dictatorship on the other side. A third alternative, an interventionist compromise, is not feasible." 34

In order to bring about interventions, enforcement power is necessary, e. g. in the form of an array/law/decree ${ }^{35}$ (without being an active market participant) or in the form of market intervention as a trading market participant according to the Keynesian demand management. Thus, interventionism is a government's economic policy, not conform with the order, with unsystematic, activist interventions in economic activity, which is not aligned with a general and coherent economic or regulatory approach, but composed by a bunch of selective, subsequently corrective, relatively unrelated and little proactive measures. ${ }^{36}$

\section{Money and fiscal policy}

Money policy: First of all, from the beginning of World War I, an undermining of the currency has taken place, as the central bank (German Reichsbank) drastically changed the structure of the

\footnotetext{
30 Cp. Mises, L. (1940/1998), p. 10.

31 Cp. Mises, L. (1976), pp. 5-6.

32 Cp. Mises, L. (1940/1998), p. 1.

33 Cp. Mises, L. (1976), pp. 3-5.

34 Cp. Mises, L. (1940/1998), p. 92.

35 Cp. Mises, L. (2008), pp. 714-715.

36 Cp. Ramb, B.-T. (2014).
} 
monetary base between 1913 and 1923, from a gold backing ${ }^{37}$ of onethird to $75 \%$ paper money and $25 \%$ deposits of the private sector. ${ }^{38}$ During the war alone, Germany has increased its money supply by $400 \% .{ }^{39}$ The repressed inflation resulting from the shortage of goods in connection with the post-war elimination of price controls ${ }^{40}$ and a glut of money gave a considerable boost to inflation ${ }^{41}$ after $1918,{ }^{42}$ as it was worthwhile for everyone to top up their inventories, due to rising prices. ${ }^{43}$ The Reichsbank granted the state ever higher loans and only recognized in May $1921^{44}$ the perishable consequences of the increasing monetary devaluation by the excessive expansion of the circulation of money. However, this did not prevent the bank from increasing the money supply exponentially as of 1922. In that year, the government lost all control over the budget deficit ${ }^{45}$ and pursued a policy of systematic inflation. ${ }^{46}$ Despite the independence of the Reichsbank from the German Reich as of 1922, it sees itself forced, until 1923, to give the government ever larger loans and, at the same time, to counteract the devaluation of the currency and the decline of the exchange rate by interventions. ${ }^{47}$

Only the discount policy shows the aim of the Reichsbank to devaluate the government debt by financial repression. Thus, the discount rate was 5\% p.a. ${ }^{48}$ since the end of 1914 to July 1922, while inflation in July 1922 was $100.5 \% .{ }^{49}$ In its meetings, the Reichsbank consistently refused to increase the discount rate to a higher level. ${ }^{50}$ Shortly before the collapse of the Mark and the currency cut in

37 Cp. Roesler, K. (1967), pp. 37-38.

38 Cp. Holtfrerich, C.-L. (1980), pp. 58-59.

39 Cp. Ahamed, L. (2016), p. 177.

40 Cp. Holtfrerich, C.-L. (1980), p. 76.

41 Cp. Kiehling, H. (1998), p. 14.

42 Cp. Martin, P. (2016), pp. 32-34.

43 Cp. Aldcroft, D. (1978), pp. 74-83.

${ }^{44}$ Cp. Landsburgh, A. (1924), pp. 35-36.

45 Cp. Ahamed, L. (2016), p. 278.

46 Cp. Ahamed, L. (2016), p. 177.

47 Cp. Deutsche Reichsbank (1925), pp. 93-94.

48 Cp. Deutsche Reichsbank (1925), table section, pp. 94-95.

49 Cp. Statistisches Reichsamt (1924), pp. 284- 285.

50 Cp. Havenstein, R. (1923), p. 125, Footnote 2 and pp. 106-107. Havenstein explains literally: "Until July 28, 1922 we held the discount at a rate of 5\%, which has existed since December 1914. We felt compelled to do so, because until then the great liquidity 
November 1923 , the discount rate was $90 \%$ p.a., ${ }^{51}$ and the inflation was 7,094 million $\% .{ }^{52}$

GRAPH 2: THE GERMAN INFLATION 1914-1923 — DEVELOPMENT OF CENTRAL BANK MONEY STOCK AND WHOLESALE PRICES

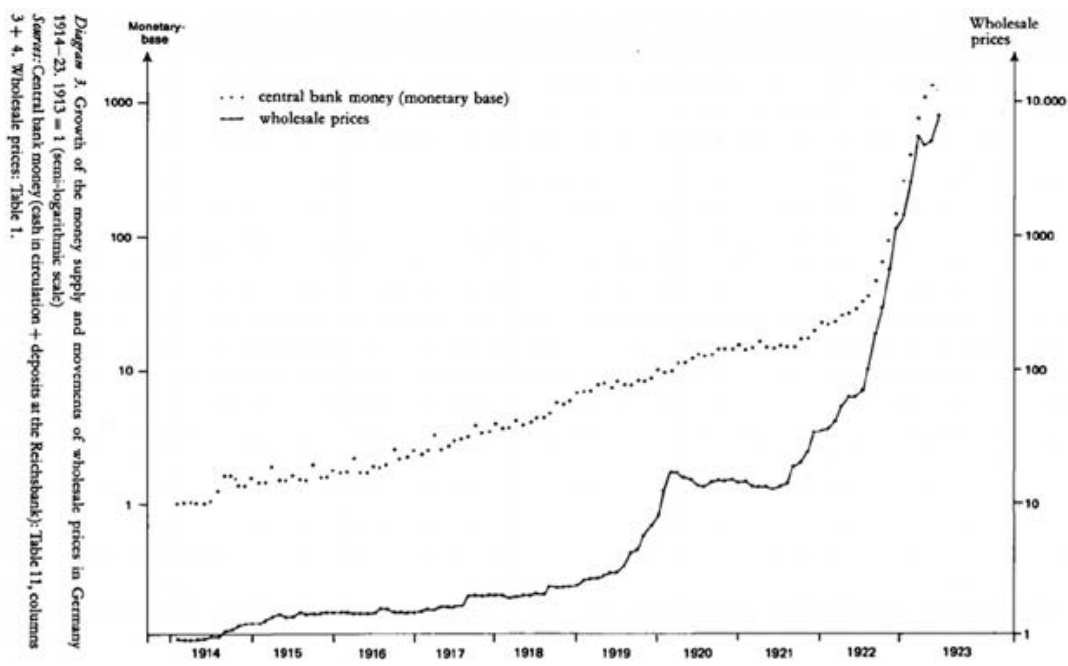

Source: Holtfrerich, C.-L. $(1986)^{53}$.

Finally, the devaluation of the Mark was, according to Bresciani-Turroni, a result "of the quantity of money, issued by the

made cash transactions the norm and the demands placed on us by the economy were comparatively small and did not matter at all as compared to the credit claims of the Reich. Of course, the purpose of restricting the withdrawal of credit, as pursued by a discount increase, is out of question, as far as credit claims of the Reich are concerned, because the Reich must procure the means for the imperial necessities, regardless whether the discount rate for the treasury notes is higher or lower. Furthermore, it must be borne in mind that the profits resulting from discounting largely flow back to the Reich as a result of its profit sharing, and that the Reich is less interested in the level of the discount rate.

51 Cp. Deutsche Reichsbank (1925), table section, p. 95.

52 Cp. Statistisches Reichsamt (1924), pp. 284- 285.

53 T.f. Holtfrerich, C.-L. (1986), p. 100. 
government. It was only the continual increase in the issue of legal money which made possible the incessant rise in prices and the continual fall in the external value of the Mark". ${ }^{54}$ Neither government nor Reichsbank wanted to recognize the causes: their own monetary policy. Havenstein, the President of the Reichsbank, did not see that his printing of new money was responsible for the devaluation of the currency and that he pointlessly has sacrificed foreign currencies to the amount of 230 million Mark to stabilize the Mark by intervention. ${ }^{55}$

GRAPH 3: DEVELOPMENT OF GOLD, INDEX OF STOCK PRICES AND CONSUMER PRICE INDEX ${ }^{56}$

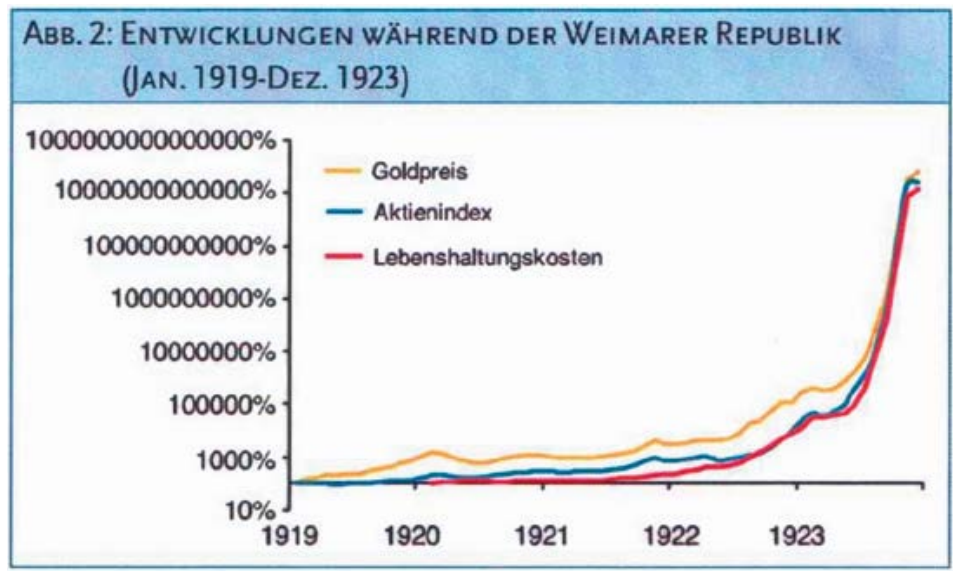

Quelle: „Wirtschaft und Statistik“, S. 12 - 15, „The Economics Of Inflation A Study OfCurrency Depreciation In Post War Germany“, Silberjunge

Source: Bresciani-Turroni, C. (2007), Wirtschaft und Statistik.

The cause was the budget deficit, which provoked continual issues of paper money. ${ }^{57}$ Already during the war, especially from

\footnotetext{
${ }^{54}$ Cp. Bresciani-Turroni, C. (2007), pp. 398-399.

55 Cp. Bresciani-Turroni, C. (2007), p. 46.

56 T.f. Flierl, R. (2009), p. 46.

57 Cp. Bresciani-Turroni, C. (2007), p. 47.
} 
autumn 1916 onwards, the revenues from the issued war bonds were always less than the amount of the floating debt. Therefore, the floating debt amounted to 46 billion Mark in September 1918. ${ }^{58}$

GRAPH 4: GERMAN PUBLIC DEBT SINCE 1850 (IN PERCENT OF THE GDP)

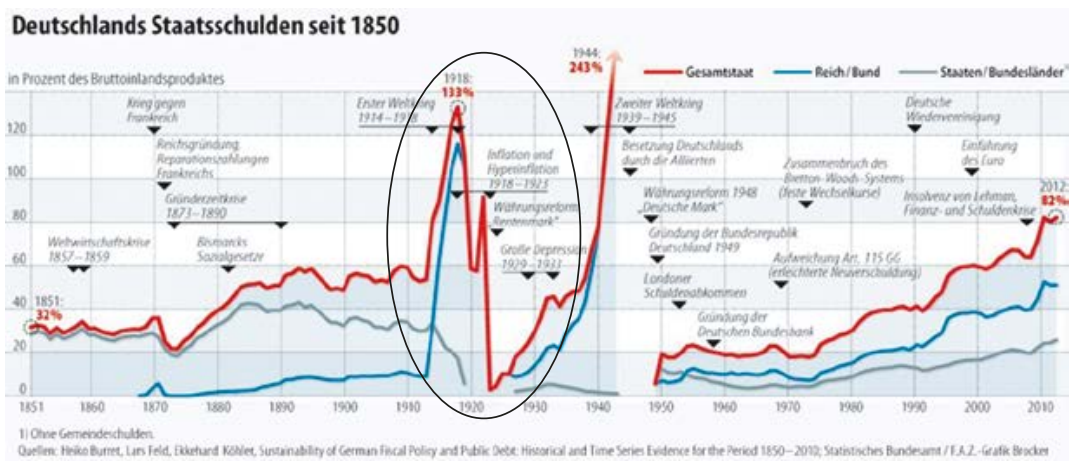

Source: FAZ ${ }^{59}$.

For foundations, the 1919-1923 inflation years initially eroded the foundations' capacity, because the interest income of social capital could provide less and less real aid to the poor and needy, due to the rapid loss of purchasing power decreasing from month to month. This is mainly because nominal interest income in absolute terms remained relatively stable during the period of inflation, since social capital was invested in longer-term bonds, and, at the same time, the citizens' misery constantly increased, due to the massive loss of purchasing power of their money.

Even if the fiscal and money policy have led to the devaluation of the social capital it must be critically questioned why the majority of social capital was invested in debt securities and primarily in covered bonds, government and war bonds and contained almost no productive assets.

\footnotetext{
${ }^{58}$ Cp. Bresciani-Turroni, C. (2007), p. 48.

59 T.f. FAZ (2013).
} 


\section{Spiral of intervention}

The main causes of this catastrophe for social capital as well as for the population and, therefore, the starting point of the investigation were the state interventions in the foundation business.

Before that, in the first centuries of the foundation system in Germany, founders donated without regulations, the assets required for the foundation's purpose to their foundations. ${ }^{60}$ Most of these were hospitals, ${ }^{61}$ schools or homes, ${ }^{62}$ i.e. the donor erected the building, which was then donated to the public welfare.

In the course of industrialization, there was a foundation start-up boom and the overwhelming majority of foundations were founded as capital funds in the $19^{\text {th }}$ century, as both confidence in the currency and in the state prevailed. ${ }^{63}$ At that time, the government began to regulate the foundation system and to channel investment flows. ${ }^{64}$

The right of intervention of the state was legitimized by the duty that foundations must be approved before their establishment by the government, ${ }^{65}$ which was prescribed in many German Länder even before the foundation of the German empire in 1871, in order to prevent foundations from financing an overthrow of the government or immorality. ${ }^{66}$ With the introduction of the Civil Code the permit requirement was generally legitimate in the German empire. This made it clear that foundations could only operate within the framework set by the state, and that the government had overall supervision and control over this autonomous capital.

When analyzing the multitude of interventions that either directly affected social capital or had a side-effect on it, an intervention spiral becomes evident, which is described in chronological order below, together with the unintended consequences.

\footnotetext{
60 Cp. Anheier, H. (2003), p. 72.

61 Cp. Stadt Wunsiedel (n.y.)

62 Cp. Scheller, B. (2004), p. 156.

63 Cp. Adam, T. (2009), p. 179.

64 Cp. Kiesinger, K. G. (1968), pp. 55-56.

65 Cp. Hecht, F. (1875), pp. 16-17.

66 Cp. Savigny, F. (1840), p. 278.
} 
The pivotal and central point for the catastrophe in 1923 was the governmental intervention from the $19^{\text {th }}$ century onwards in the capital investments of foundations by the gilt-edged regulation. ${ }^{67}$ The new state regulations intervened in the group of persons which invested hitherto donation funds as well as in the selection of money investments. ${ }^{68}$ As a result, the public authorities have channeled this balance through the guilt-edged-rule to certain "investments" which have made these funds almost entirely serviceable to the credit needs of the Reich, the provinces and municipalities, agriculture and housing, and so make these amounts inaccessible to other borrowers. ${ }^{69}$ This was justified by the inability of previous guardians and the corrupt mortgage system. ${ }^{70}$ According to the new giltedged rule, the foundation capital was first invested in land and mortgages, ${ }^{71}$ and subsequently in government bonds. ${ }^{72}$ The state has arbitrarily defined the composition of gilt-edged investments. ${ }^{73}$

However, foundation funds were already invested prior to the introduction of these regulations, and since investments abroad (e. g. Austrian government bonds) have been more profitable for decades, ${ }^{7475}$ economically acting foundation boards decided to continue investing in these bonds. The additional income together with the downward money market ${ }^{76}$ also led to an increase in endowment capital. ${ }^{77}$

The German government's order issued in 1882 that foundations that had invested in Austrian covered bonds had to sell them

67 Cp. Hecht, F. (1875), pp. 16-50, p. 84: In Baden as of May 5, 70, Bavaria as of July 31, 1869; Hessen-Darmstadt: as of Dec. 18.12.1838, as of 9.12 .1865 also railway obligations (pp. 49-50), Preußen as of 8.5.1821 (p. 84).

68 Cp. Camphausen, A. v. (2003), p. 72.

${ }^{69}$ Cp. Schumpeter, J. (2008), p. 313.

70 Cp. Thünen, J. (1844), pp. 157-161.

${ }^{71}$ Cp. Hecht, F. (1875), pp. 11-144.

${ }^{72}$ Cp. Kiesinger, K. G. (1968), p. 56.

73 Cp Adam, T. (2009), p. 185.

74 Cp. Österreichisches Reich (1868), state bond issue 1868, 5\% interest rate and half-year payment.

75 Cp. Cholet, J. (1988), p. 163; Baumstark, E. (1833), p. 595: bonds of the Prussian state with interest rates between $3,5 \%$ to $4,5 \%$.

${ }^{76}$ Cp. Hecht, F. (1902), p. 6.

77 Cp. Adam, T. (2009), p. 184. 
(with price loss) was political motivated. ${ }^{78}$ Only gilt-edged investments of the German Reich were permitted. ${ }^{79}$ One of the reasons for this may have been that the German government was not always able to sufficiently finance its borrowing requirements for urban development and public health care in the market, since foreign issuers offered more attractive interest rates. ${ }^{80}$ It is characteristic that financing the own state requirement has priority over the obligation to preserve capital.

The strong influx into the cities, due to the industrialization, made it urgently necessary to create housing. At the same time the agricultural economy had to be realigned, because of the departure of workforce, and for the economic interests of the remaining rural population the agricultural loan needed to be promoted. ${ }^{81}$

Capital was urgently needed for both purposes, and the government intervened again. With an innovation, the construction of an organized "real credit market", which was "vigorously supported" by the government in Bavaria, ${ }^{82}$ the necessary capital was created, which was an urgent prerequisite for the rapid growth in the cities as of 1870.83

The result was that it was almost impossible to directly contract real mortgages, and foundations were crowded out as private mortgage lenders. This becomes evident by the fact that foundations invest more and more in government bonds and covered bonds ${ }^{84}$ although real estate and mortgages were top priority ${ }^{85}$ in the investment regulations of most German Länder and government bonds and covered bonds only came afterwards in the order

78 Cp. Adam, T. (2009), p.

79 Cp Universitätsarchiv München (1911): Bestand I (Stipendien), I-III-29 (v. Lamontsches Stipendium), Maschinenschriftliche Aktennotiz ad 1368/11 aus dem Jahre 1911 (angeheftet an den Brief des Verwaltungsausschusses der Ludwig-Maximilians-Universität an den Akademischen Senat der K. Ludwig-Maximilians-Universität vom 15. April 1911), cited in Adam, T. (2009), pp. 184-185.

80 Cp. Hecht, F. (1902), pp. 5-7.

81 Cp. Rittershausen, H. (1929), p. 73.

82 Cp. Hecht, F. (1875), p. 163.

83 Cp. Hecht, F. (1892), p. 5.

84 Cp. Hecht, F. (1908), pp. 27-29.

85 Cp. Hecht, F. (1908), pp. 27-29. 
of approved papers. Usually, the bonds had a nominal interest rate of 3 to $3.5 \% .86$

The unconditional desire to expand the covered bond market as a source of funding can be seen from the fact that rural covered bond loans were offered without any profit. ${ }^{87}$ And also, the condition of the amortization was dropped in case of strong opposition, because nobody wanted to scare off borrowers and push them in the arms of foundations, savings banks and foreign mortgage banks. ${ }^{88}$

As of 1 January 1900, the Reich Mortgage Bank Act (Reichshypothekenbankgesetz) classified all covered bonds and all landscape bonds in Germany (to subsidize the agricultural sector) as gilt-edged investment. ${ }^{89}$ With this admission, the option of offering private mortgages at individually negotiable interest rates was finally ousted from the market. ${ }^{90}$ At the same time, deposits at savings banks were declared as gilt-edged investment, too. ${ }^{91}$

The subsidy through the gilt-edged status resulted in the fact that from 1888 to $191390 \%$ of all bond issues were government bonds, municipal bonds and covered bonds and only $10 \%$ were industrial bonds ${ }^{92}$, which shows the effects of the capital governance and the consequences for the economic development of Germany, as described in section 5.2. very well. Furthermore, because social capital was only investable in the above-mentioned kinds of investment and was through state control not available to other borrowers on the market, a difference in interest rates has arisen which can not, or not entirely, explained by the risk difference. ${ }^{93}$ This interest rate differential between the state-favored investments and investments of other debtors split the investment market into beneficiary debtors who have to pay a lower interest and not favored debtors.

\footnotetext{
86 Cp. Hecht, F. (1876), p. 68, p. 75, p. 86.

87 Cp Hecht, F. (1892), p. 7.

88 Cp. Hecht, F. (1892), p. 6.

89 Cp. Rittershausen, H. (1929), p. 30, p. 84, p. 711.

90 Cp. Hecht, F. (1908), p. 28.

91 Cp. Adam, T. (2009), pp. 185.

92 Cp. Adam, T. (2009), pp. 190-191.

93 Cp. Schumpeter, J. (2008), p. 313.
} 
The demand for houses increased, because of the new opportunity of easy capital raising, which led to strong price increases of real estate in some cities. To curb this price increase in real estate, the cities of Frankfurt and Hamburg introduced a progressive capital gains tax on profits when selling real estate in 1906, while other cities initially looked at the tax-related experience. ${ }^{94}$ The consequence of the market intervention via the tax was that property owners avoided sales, ${ }^{95}$ and the prices continued to rise. It became increasingly difficult for foundations to invest in real estate. Thus, they were increasingly forced to the approved debt securities. Diversification of social capital is becoming more and more difficult as real assets become both scarcer and more expensive.

This trend was intensified at the beginning of the war, which becomes evident from the government's attitude: “Today, all available money belongs to the fatherland, and today war bonds are the investment paper". ${ }^{96}$ First of all, the government recommended foundations to buy war bonds, which had a $1 \%$ higher interest rate than the German key interest rate. ${ }^{97}$ Since foundations did not buy war bonds to the extend as expected by the state, a decree was issued on 14 September 1916 to facilitate the purchase of war bonds by foundations, ${ }^{98}$ later, coercion was applied. ${ }^{99}$

Financial experts knew at that time that war bonds were a bet on victory, i. e. if Germany lost the war, the money was gone. ${ }^{100}$ This insight may have been the reason why some foundations, or rather foundations in certain regions of Germany, opposed governmental orders. For example, the share of war bonds in Freiburg and Münster was well below that of most foundations in other regions and cities. ${ }^{101}$

94 Cp. Köppe, H. (1906), pp. 1-3.

95 Cp. Köppe, H. (1906), p. 3.

96 Cp. Helfferich, K. (1915a), p. 225, own translation of: „Heute gehört alles verfügbare Geld dem Vaterland, und heute sind die Kriegsanleihen das Anlagepapier".

${ }_{97}$ Cp. Horn, T. (2014), p. 28.

98 Cp. Adam, T. (2015), p.30.

99 Cp. Adam, T. (2009), pp. 194-195.

100 Cp. Häussler, F. (2018).

101 Cp. Adam, T. (2009), p. 192, p. 196. 
After the war, public debt (sovereign bonds and war bonds) was almost unmanageable. ${ }^{102}$

The German Reichsbank was another institution that intervened in the market, especially as of the beginning of the war, and gradually devalued the German currency by quickly increasing the circulation of bank notes and bypassing the one-third gold backing 103 to support war financing. Furthermore, the Reichsbank, together with its newly founded subsidiary (Darlehenskasse), increased the money supply in order to provide sufficient financing both for the state and industry. ${ }^{104}$

The Reichsbank was authorized to include loan fund certificates (Darlehenskassenscheine), which counted as legal means of payment, in the gold backing, and, thus, the circulation of the Reichsbank notes could be extended unlimited. ${ }^{105}$ The amount of paper money alone increased six-fold from September 1914 to December 1918. ${ }^{106}$

The devaluation of money progressed more and more with an increasing inflation of the money supply. Nevertheless, the Reichsbank kept interest rates at a low level of 5\% and $6 \%$ over a period of 7.5 years ${ }^{107}$ in order to keep the interest burden of the Reich as low as possible, as this had to be financed from the regular budget. ${ }^{108}$ Ultimately, the national bankruptcy was only delayed.

A few foundations opposed the massive devaluation of their foundation capital, for example the Kaiser Wilhelm Society with its foundations. Because interest rates were insufficient to meet the dramatic increase in inflation costs, the management committee decided in spring 1922 to sell war bonds to the amount of 18 million Mark and reinvested the foundation assets in industrial stocks. ${ }^{109}$ By the end of the year, the price of these shares had risen

\footnotetext{
102 Cp. Helfferich, K. (1915), p. 34.

103 Cp. Spoerer, M. et al. (2013), p. 38.

104 Cp. Horn, T. (2014), p. 34.

105 Cp. Spoerer, M. et al. (2013), p. 39.

106 Cp. Henning, F.-W. (1988), pp. 45-50.

107 Cp. Deutsche Reichsbank (1925), table part pp. 94-95.

108 Cp. Kiehling, H. (1998), p. 20.

109 Cp. Biedermann, W. (2011), p. 17.
} 
to 64 million Mark ${ }^{110}$, due to hyperinflation. That this was not the complete compensation of the currency depreciation becomes evident from the respective conversion into Goldmark. While in spring 18 million Mark corresponded to some 257,000 Goldmark, the equity portfolio was only equivalent to 44,000 Goldmark at the end of the year. ${ }^{111}$ Although the investment of foundation assets had to be made according to the gilt-edged regulation, the exchange of war bonds to industrial shares of the Kaiser Wilhelm Society was approved by government representatives. ${ }^{112}$

Most of the foundations, however, had a false sense of security, as the prices of some government bonds rose sharply from mid-July 1922 onwards. ${ }^{113}$ Only on June 23, 1923 - shortly before the catastrophe, when the purchasing power of the foundation income was tiny and the gap between prices of bonds measured in purchasing power and prices of shares became huge - was the gilt-edged law altered, due to the massive loss of purchasing power. With governmental approval the foundations could also buy other assets if the investment was not contrary to economic asset management. ${ }^{114}$

The government feared that if there was an explicit commitment to values, then it would come to a run on savings banks, and the prices of government bonds and war bonds would fall. The easing rule had practically no effect, due to its concept, ${ }^{115}$ and it was too late.

How many foundations at that time were still able to save parts of their capital by exchanging in tangible assets is not known, because the purchasing power was already totally eroded. ${ }^{116}$ The state was so astronomically indebted and solved the problem in fall 1923 by the currency reform of Nov. 15, 1923, which was a de facto state bankruptcy: ${ }^{117}$ Public debt was virtually completely devalued by the conversion of 1 trillion Mark to 1 new Rentenmark. The entire

110 Cp. Biedermann, W. (2011), p. 18.

111 Cp. Biedermann, W. (2011), p. 18.

112 Cp. Biedermann, W. (2011), p. 18.

113 Cp. Kiehling, H. (1998), p. 20.

114 Cp Reichstagsprotokolle (1923, 1923a): June 16, 1923, Adoption of the law and June 23, 1923 Legal text and justification.

115 Cp. Rittershauen, H. (1929), p. 13, p. 33; Kipp, T. (1923), p. 513.

116 Cp. Deutscher Reichstag (1923): Member of Parliament Karsten on June 15, 923

117 Cp. Cp. Spoerer, M. et al. (2013), p. 47. 
war bonds to the nominal amount of some 16 billion Mark only had a real value of 16 Pfennig 118 after the currency reform and were written off from the custody accounts as worthless. ${ }^{119}$

When foundations had offered mortgages, the borrowers tried to repay them with de-valued money, and the courts often had to represent the government's policy. ${ }^{120}$

After the currency reform, the foundations still had some hope that the policy would revalue the foundation capital to a great extent, as they were forced by the state to these investments and an appreciation would be fair. ${ }^{121}$ Finally, with the Loan Dissolution Act (Aufwertungsgesetz) of July 16, 1925 this has proven as a fallacy. Government bonds were devalued to $2.5 \%$ of the original debt, ${ }^{122}$ only covered bonds were valued at $12.5 \%$ of the nominal value, as well government bonds, for which a right to draw was valid. ${ }^{123}$ The conditions of the revaluation were hardly suitable for resuming the support activity. ${ }^{124}$

The investment provisions for the social capital were made by state decrees, bids and prohibitions. Therefore, the claim stated by Carl-Ludwig Holtfrerich that everyone had it in their own hands whether he /she was affected by inflation ${ }^{125}$ must be clearly contradicted with respect to foundation assets. The German state has used the entire accumulated social capital for state tasks by channeling the foundation funds through the gilt-edged rule, from the expansion of the welfare state to war financing. ${ }^{126}$

The abovementioned measures form, with the change between intervention and following unintended side-effects or

118 Cp. Haffert, L. (2015), n. pag.; Hacker, M. (2013), p. 187.

119 Cp. Horn, T. (2014), p. 297.

120 Cp. Horn, T. (2014), p. 298.

121 Cp. Anon. (1926), p. 17.

${ }^{122}$ Cp. Adam, T. (2009), p. 198.

123 Cp. Adam, T. (2009), p. 198.

124 Cp. Adam, T. (2009), p. 198. The repayment of the appreciation amount was drawn in installments over 30 years and the interest paid only on repayment. As a result, there was no income until repayment of the interest on appreciation. Since foundations are only allowed to issue the proceeds, no project could be financed from the interest of the revaluation claim until the draw.

125 Cp. Holtfrerich, C.-L. (1980), p. 117.

126 Cp. Adam, T. (2018), p. 15. 
circumvention of the prohibitions ${ }^{127}$, an intervention spiral as the graph below illustrates:

\section{GRAPH 5: SPIRAL OF INTERVENTION - CHANGE OF STATE INTERVENTIONS AND UNINTENDED SIDE-EFFECT OR CIRCUMVENTION OF THE PROHIBITIONS}

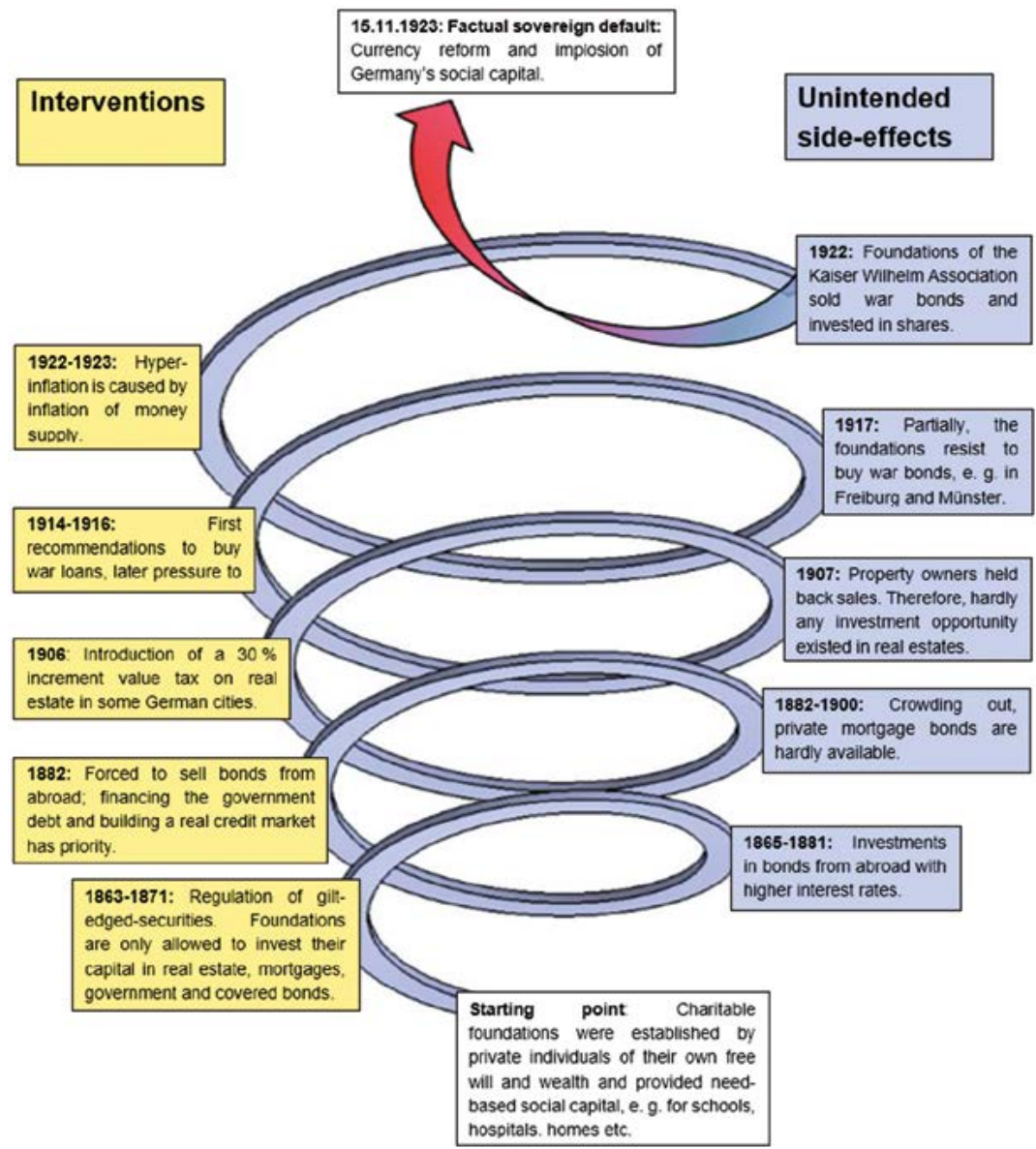

Source: Own presentation.

127 Cp. Blankart, C. (2017), pp. 202-203. 


\section{Spiral of intention}

When analyzing the individual intervention steps, it becomes evident that with every further intervention, the motivation of the government changes.

While the first intervention is solely for the purpose of special protection to ensure that social capital is as secure as possible, the focus on this objective is more and more diminished with every additional intervention, since the state has recognized that it can also serve the needs of others groups by controlling social capital. After all, the state also wants to support its own projects. Therefore, the care of the state simply turns to self-interest, finally culminating in forcing foundations to invest social capital in war loans. Rittershausen excellently describes that the interventions are not always based on the same intention: "Nowhere else in the world is selfishness compatible with selfless care. The state cannot take protective measures for ward and savings funds and, at the same time, combine the fiscal policy purpose of obtaining cheap credit for itself". ${ }^{\prime 28}$

Each intervention increases the damage. When the disaster is imminent, the state tries to remove the guilt by slightly changing the gilt-edged rule, so that in case of damage the responsibility lies with the foundation board.

The graph below shows the spiral of intention based on the step-by-step interventions: 
GRAPH 6: SPIRAL OF INTENTION - THE LONGER THE PROCESS, THE GREATER THE DESTRUCTION

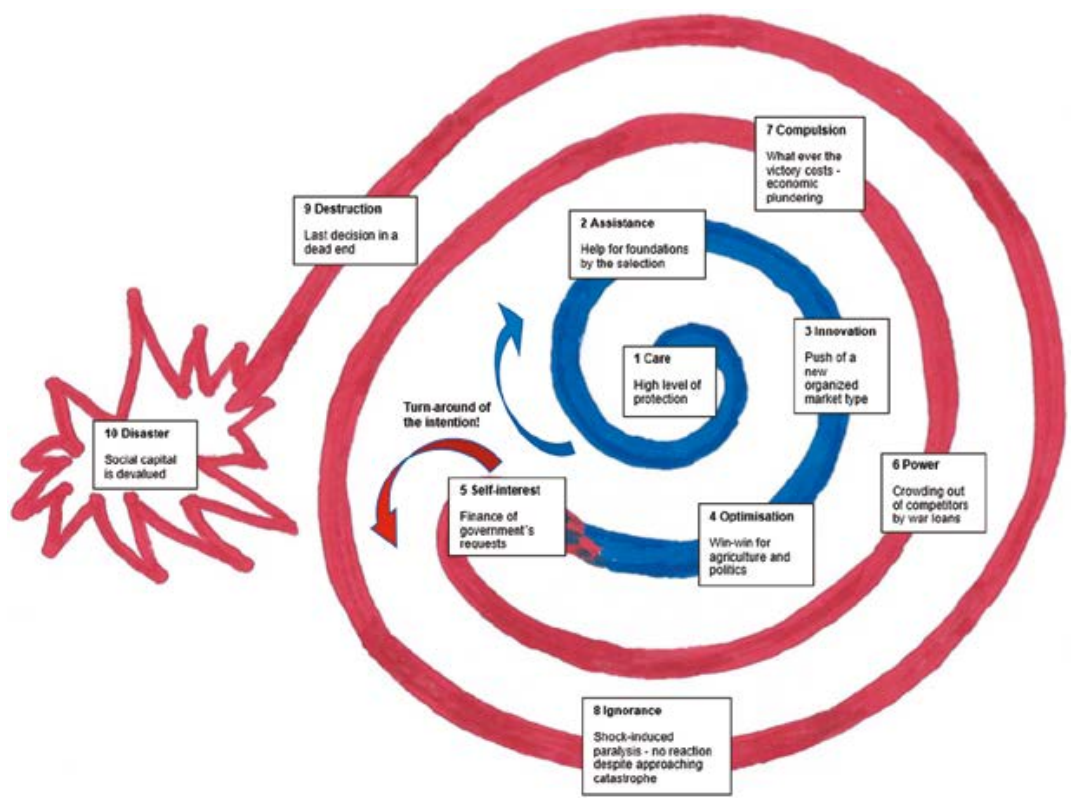

Source: Own presentation.

\section{IV \\ WHAT WOULD THE AUSTRIAN ECONOMISTS SAY?}

Even though charitable foundations in Germany are a special segment of an economy, the teachings of the Austrian School of Economics can also be applied to the development of social capital and its fate in the interwar period.

\section{The fatal conceit}

The rules for investing foundations capital highlight the governing state's arrogance which believed to have a better understanding of capital investments than many foundation board members. Otherwise, there would be no reason to believe that asset management 
expertise cannot be expected from foundation managers. ${ }^{129}$ This presumption of knowledge ${ }^{130}$ is regarded as actual knowledge and expertise in the population. The problem is exacerbating because, according to Rittershausen, many non-regulated capital owners also invest their assets in the same way to protect it against all coincidences. In particular, these are elderly people who have withdrawn from their business, state and local officials, scholars, lawyers, intellectual workers, teachers, widows; in short, all those who either stay out of business, as a result of their work or who do not have the necessary time or knowledge for a closer examination of the investments. ${ }^{131}$ This confirms Hayek's opinion again, who certifies intellectual ignorance in economic matters. ${ }^{132}$

But also, in the money market policy of the German Reichsbank presumption of knowledge is recognizable, because the central bank tries to control money supply, although its knowledge on supply and demand is never objective. ${ }^{133}$

\section{Currency and credit manipulation}

With his question "What has the government done to our money"134 Murray Rothbard exactly illustrates the main responsibility for the disaster. The government, which has the monopoly on money, abolished the one-third gold backing ${ }^{135}$ just before the start

129 Cp. Rittershausen, H. (1929), pp. 64-65.

130 Cp. Hayek. F. (1988), pp. 98-99. The review of Heinrich Rittershausen shows the arrogance of the provision for safe investments for foundations. "One" regulates "a matter by law in such a way that - for lack of knowledge of the actual economic correlations - necessities of secondary character, i. e., for example, the promotion of state loans, have been made a leitmotif of regulation. The result is that savings are wrongly invested, and are largely used unproductively, so that afterwards the future needs, for which one had saved, cannot be covered anymore. If one had been aware of the economic context, one would have, above all, not intervened in the free movement of capital, not given single capital consumers a monopoly and excluded others, but allowed the interest rate to have its regulatory function".

\footnotetext{
${ }^{131}$ Cp. Rittershausen, H. (1929), pp. 7-8

132 Cp. Hayek, F. (1988), pp. 100-101.

133 Cp. Huerta de Soto, J. (2012), p. 657.

134 Cp. Rothbard, M. (1990/2005), p. 10.

135 Cp. Roesler, K. (1967), pp. 37-38.
} 
of the war, so that an unlimited money production was made possible with treasury notes by the subsidiary of the Reichsbank, i. e. to create money from the air. ${ }^{136}$

Fractional reserve banking system produce crises, ${ }^{137}$ because artificially created capital does not come from voluntary savings, but states have legalized privileges through fiat money in order to take advantage of them, e. g. to create loans ex nihilo, which are given to the government itself. ${ }^{138}$ The state finances itself in the easy way through loans and inflation, ${ }^{139}$ and the central bank delays and aggravates the economic crisis by liquidity supply in times of crisis. ${ }^{140}$

Especially in difficult economic times the government wants the central bank to create wealth through money-making ${ }^{141}$ and, thus, to stimulate the economy. ${ }^{142}$ The German Reichsbank printed unlimited money, and the quantity of money finally exploded, as the graph in chapter 3.2. shows.

If the money supply is not equivalent to the corresponding amount of goods, not only inflationists, but also parts of the population recognize over time that this will reduce the purchasing power ${ }^{143}$ or increase inflation, defined as an expansion of the money supply. ${ }^{144}$ However, the price increase is not evenly and simultaneously distributed across all goods, according to the Cantillon effect. ${ }^{145146}$ The desired positive effect of inflation by printing money is very limited, because it only works as long as the prices for all goods and services have not adapted accordingly. ${ }^{147}$

Due to the inflationary prices the demand for money is initially higher. Schumpeter describes this as over-disposition, which is

\footnotetext{
136 Cp. Rothbard, M (1990/2005), p. 55.

137 Cp. Huerta de Soto, J. (2012), p. 657.

138 Cp. Huerta de Soto, J. (2012), p. 647.

139 Cp. Huerta de Soto, J. (2012), p. 648.

140 Cp. Huerta de Soto, J. (2012), pp. 654-655.

141 Cp. Mises, L. (1924), p. 203.

142 Cp. Mises, L. (1924), pp. 208-210.

143 Cp. Mises, L. (1924), p. 204.

144 Cp. Goulding, D. (2010), pp. 102-103.

145 Cp. Thornton, M. (2006).

146 Cp. Schumpeter, J. (2008), p. 262.

147 Cp. Mises, L. (1924), p. 209.
} 
"an essential vehicle for the degeneration of a currency."148 The state benefits from the fact that in times of surprising hyperinflation, loans pay off themselves ${ }^{149}$, because without inflation the repayment of the immense public debt is impossible. ${ }^{150}$

GRAPH 7: INCREASE IN MONEY SUPPLY

AND INCREASE IN THE INFLATION RATE GO HAND IN HAND

Figure 2. Inflation and Money (M2) Growth 1/ 1960-95 averages

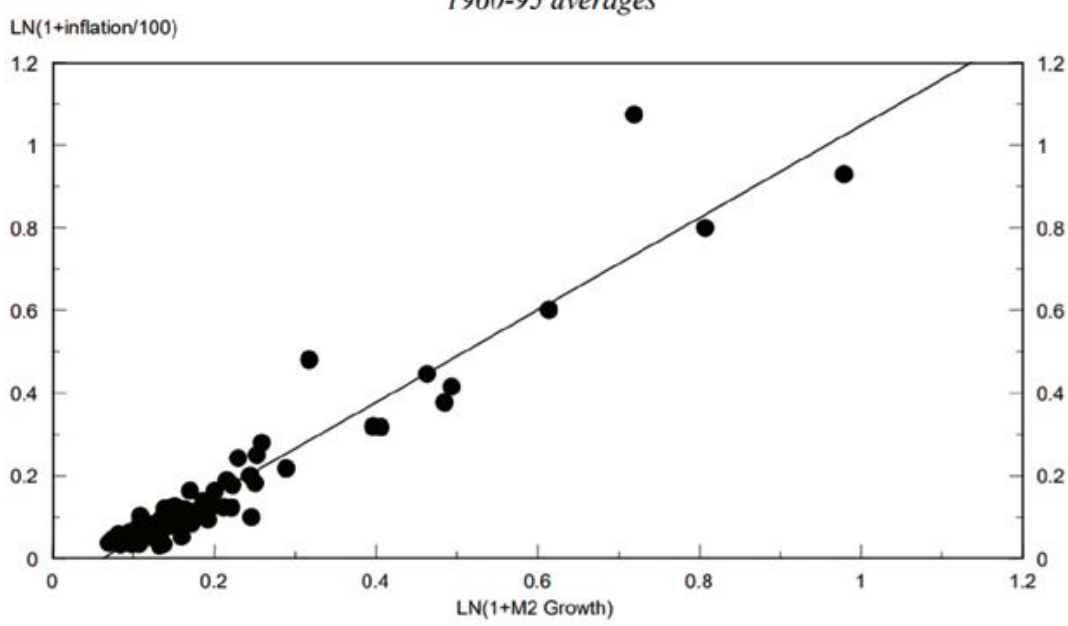

1/ Slope of regression line is 1.115 with a t-statistic of 12.13;94 countries in total, each with 10 or more observations.

Source: Fischer, S./Sahay, R./Végh, C. (2002).

The German Reichsbank also helped in this process by the financial repression, as it left the discount rate at $5 \% 151$ until mid-1922, even though inflation was already around 20 times higher at that time. ${ }^{152}$

148 Cp. Schumpeter, J. (2008), p. 252 f, own translation of: „(...ein wesentliches Vehikel der Degeneration einer Währung...)“.

149 Cp. Mises, L. (1924), p. 204.

150 Cp. Bagus, P. (2012).

151 Cp. Deutsche Reichsbank (1925), table section, pp. 94-95.

152 Cp. Statistisches Reichsamt (1924), pp. 284- 285. 
Thus, on the formation of the interest rate there was also an intervention in the free play of market forces. ${ }^{153}$

The correlation between the increase of money supply and inflation rate, as detected by the Austrians, is proven by the graph above, based on a study of 94 countries which have inflation rates above $100 \%$ p.a. ${ }^{154}$

Rothbard explicitly mentions the widows and orphans which were robbed by state inflation in favor of subsidies for farmers and workers in the arms industry, ${ }^{155}$ which exactly corresponds to the destruction of social capital in the inter-war period in Germany, as debt securities became worthless after the hyperinflation and currency reform. A protection for widows and orphans can only be ensured by asset classes which are not affected from inflation by government measures.

The graph below shows that a diversified investment in different asset classes still has a value after the disaster in contrast to the devaluated debt securities:

\section{GRAPH 8: THE RESULT OF DIFFERENT INVESTMENTS AFTER HYPERINFLATION AND CURRENCY REFORM}

\section{What remains of $\mathbf{1 . 0 0 0 . 0 0 0 ~ G e r m a n ~ M a r k s ~ ( M ) ~}$ foundation capital in 1924 ? \\ 1918 invested in:}

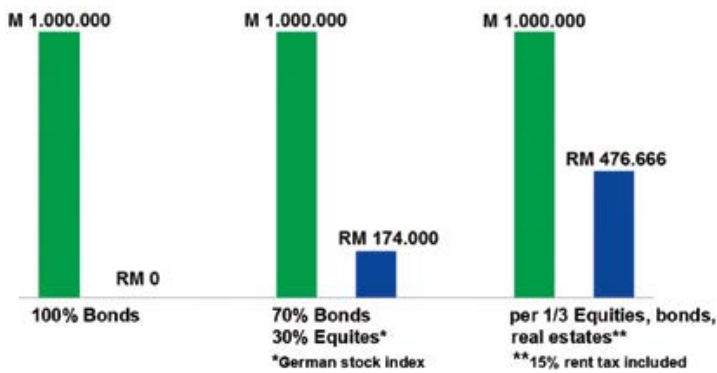

Source: Vossische Zeitung 1918, 1924, own calculations.

153 Cp. Mises, L. (1976/2013), p. 206.

154 T.f. Fischer, S./Sahay, R./Végh, C. (2002), p. 59

155 Cp. Rothbard, M (1990/2005), p. 57, Footnote 19. 


\section{Unintended side effects lead to an intervention spiral}

Mises describes intervention as the isolated command of a societal force that compels owners to use their economic goods differently than they would have done otherwise. ${ }^{156}$ The steering of capital in gilt-edged investments is the same. Therefore, interventionism is a third system (a mix of free-market economy and socialism) in which private property is regulated by the administrative interventions of a coercion apparatus. ${ }^{157}$

In order to enforce interventions actually enforcement power is necessary, e. g. in the form of orders and prohibitions. ${ }^{158}$ Thus, interventionism is a government's economic policy, not conform with the order, with unsystematic, activist interventions in economic activity, which is not aligned with a general and coherent economic or regulatory approach, but composed of a bunch of selective, subsequently corrective, relatively disjointed and little proactive measures. ${ }^{159}$

The consequences of any state intervention are unintended side-effects, ${ }^{160}$ because the intervention in the price structure also spreads over other markets or even has the opposite effect of what was intended and, therefore, the next "corrective actions" must follow. ${ }^{161}$ Thus, one intervention entails the next, since everybody - even the rulers who have commanded them - feel that this is inadequate and insufficient, and that the unsatisfactory interventions have to be replaced by more appropriate ones. ${ }^{162} \mathrm{~A}$ spiral of interventions arises which some consider as a change between state prohibitions and circumvention of the prohibitions by entrepreneurial market players, ${ }^{163}$ who oppose the cuts and the negative consequences of the intervention.

\footnotetext{
156 Cp. Mises, L. (1976), pp. 5-6.

157 Cp. Mises, L. (1976), pp. 3-4.

158 Cp. Mises, L. (2008), pp. 714-715.

159 Cp. Ramb, B.-T. (2014).

160 Cp. Mises, L. (1976), p. 7.

161 Cp. Mises, L. (1976), pp. 135-136.

162 Cp. Mises, L. (1929/2013), p. 77.

163 Cp. Blankart, p. 202-203.
} 


\section{$\mathrm{V}$ \\ FURTHER LONG-TERM EFFECTS}

After the catastrophic experience of the extensive destruction of social capital, German politicians are unwilling to give foundations more freedom and self-responsibility in the future. ${ }^{164}$ In this respect, the state continues to channel the foundation's investments and decided as a mediator, when investing in government bonds, directly on the use of the foundation's funds, ${ }^{165}$ i. e. about the social capital in the process of reconstruction.

\section{Development of the welfare state}

Due to the destruction of social capital, foundations have been eroded as autonomous providers of social support. Subsequently, the expansion of the welfare state has taken place. ${ }^{166}$ The budget share of public welfare spending almost doubled in 1927 compared with the budget of 1913.167

The following graph does not only show the increase in social spending in the first democracy of Germany, the Weimar Republic, but also that at the heyday of the foundations, with their huge social capital, there was virtually no fiscal social benefits (social spending in 1900: 0,59\% of GDP): 168

\footnotetext{
164 Cp. Adam, T. (2015), p. 39.

165 Cp. Adam, T. (2015), p. 29.

166 Cp. Spoerer, M. et al. (2013), p. 50.

167 Cp. Spoerer, M. et al. (2013), p. 51.

168 Cp. Roser, M. et al. (2018).
} 


\section{GRAPH 9: INCREASE IN PUBLIC SOCIAL SPENDING AS OF THE WEIMAR REPUBLIC}

Public social spending as a share of GDP

Social spending includes, among others, the following areas: health, old age, incapacity-related benefits, family, active

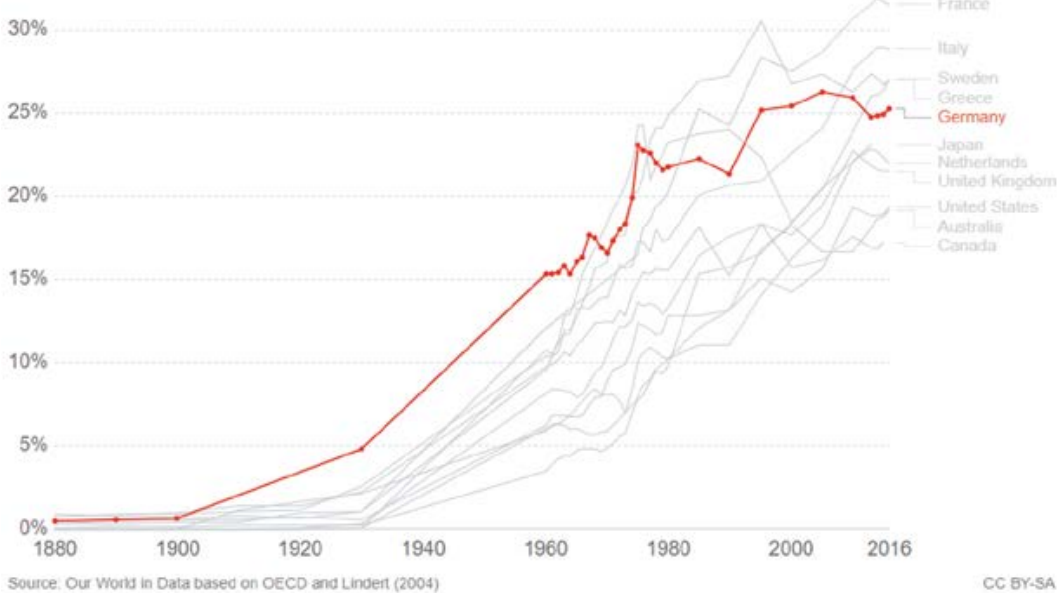

Source: Roser. M./Ortiz-Ospina, E., OECD, (2018).

After state devaluation of the foundation's assets, the state steps in for people which have until then received support from charitable foundations.

A possible explanation for the development of the social state in the Weimar period could be the link between the electoral reform in the first democracy of Germany in 1918, the destruction of social capital in 1923 and the rights of welfare recipients.

Until the electoral reform, public welfare recipients were not allowed to vote, ${ }^{169}$ so they could not penalize the state for their bad situation. Foundations, on the other hand, neither have shareholders, customers nor voters - and criticism from their "clients" is highly unlikely. ${ }^{170}$ From 1918 onwards, beneficiaries of social benefits were also allowed to vote. When the benefactors are

\footnotetext{
169 Cp. Statistisches Bundesamt (1972), p. 135.

170 Cp. Anheier, A. et al. (2004), p. 13.
} 
foundations, the state does not benefit from this situation. However, it is very rewarding for politicians to "gift" voters with social benefits in order to be re-elected. And the voter is barely willing or able to test the political decisions for success or failure. ${ }^{171}$ If social benefits had continued to be provided by autonomous social capital, it is questionable whether the state would have gained such importance as a benefactor, and whether the development of the welfare state would have taken place after the Weimar Republic. ${ }^{172}$

\section{Lack of capital in times of reconstruction of the German industry}

Even if the investment regulations for social capital are only a special field of economics, the perspective of the long-term effects of the guilt-edged rule is interesting, because the incidents had also consequences on other areas regarding the development in Germany, which are not immediately evident.

Investment rules should have contributed to the aggravation of the depression, as investing in industrial bonds was not permitted within the framework in the context of the gilt-edged investments. Therefore, the industry was cut off from long-term supply of capital available from foundations.

Despite the disaster of capital destruction due to the currency reform, the gilt-edged regulations for foundations and also for life insurance companies continued to exist. Even if "German domestic savings in the aftermath of the inflation were low"173 and also the donations of foundations, $50-75 \%$ of real savings have been invested again in government bonds, covered bonds, mortgages and real estate, ${ }^{174}$ the latter accounted for the smallest part.

171 Cp. Rothbard, M. (2009 [1962]), p. 887.

172 Cp. Ritter, G. (2010), pp. 114-115.

173 Cp. Voth, H.-J. (1994), p. 68.

174 Cp. Rittershausen, H. (1929), pp. 8-9: The Reichskreditgesellschaft estimates the annual capital formation in Germany at about $71 / 2$ billion RM in 1927 ((Deutschlands wirtschaftliche Lage", Heft 1927/28, p. 20)," so it is nearly half of the total domestic capital formation, which is more or less supplied under the compulsion of the security of the ward and application regulations to certain kinds of use intended 
Just after the war, German industry urgently needed capital for the reconstruction. However, from the domestic savings only a small percentage was left for the industry. ${ }^{175}$ The stock of deposits at banks and savings banks still was significantly reduced by shifting in war bonds. ${ }^{176}$ Therefore, foreign loans had to be taken, because domestic money was hard to obtain. Because of the very high interest rates, Germany got loans from abrod in great volume in the period 1924-1928 but largely short-term loans and only to a small part long-term investment. ${ }^{177}$ Foundation funds were — unlike in the US — not available for industrialization. ${ }^{178}$

If German companies would have been financed by tong-term capital and if foundations and life insurance companies could have provided this - without the gilt-edged rule -, this would not have resulted in a lack of capital that exacerbated when US investors withdrew their loans from Germany after the stock market crash in 1929.

Already at that time it was critically questioned whether these interventions via the gilt-edged rule and, thus, the investment channeling were good, because success depended on whether it was possible to bring the necessary capital to the right place. ${ }^{179}$

Although a sufficient number of listed stock companies existed ${ }^{180}$ at that time which had already existed for decades and also the knowledge in science was present that productive capital is an investment, from which intrinsically the yield came, ${ }^{181}$ the

by the state. If Hans Harney's comments at the VII. Allgemeine Deutsche Bankierstag in Cologne are correct, according to which capital formation can only be estimated at about 5 billion RM, then even two-thirds of the total capital formation would be subject to the regulations".

175 Cp. Rittershausen, H. (1929), p. 61.

176 Cp. Horn, T. (2014), p. 136: Deposits fell by as much as $35 \%$ during the issue phase of war loans.

177 Cp. Anderson, B. (1949), pp. 239-241.

178 Cp. Adam, T. (2015), pp. 28-29, cited McCarthy, K. (2003), p. 5, p. 45, p. 81.

179 Cp. Rittershausen, H. (1929), p. 82.

180 Cp. Gielen, G. (1994), p. 20. In 1902, 536 joint stock companies were admitted to official trading, in 1906 there were already 812.

181 Rittershausen refers to analyses that state that the market for industrial bonds did not give rise to complaints neither before the war nor even today in Germany or abroad. Cases of suspension of payment have been very rare, probably significantly less in percentage terms than states' and cities' suspension of payment. He also refers 
government intervened further in the normal distribution market of investment-seeking funds, so that the capital was not used at the level of the highest economic efficiency.

The consequences of that capital shortfall are briefly listed below:

- Between six and eight billion Reichsmarks, which went into agriculture between 1925 and 1928, have been used largely unproductively for covering losses. The state relief actions and the race for loans granted by the government ${ }^{182}$ prevented rationalizing reconstruction work. ${ }^{183}$

- The industry has been cut off from its sources of capital, the urgent need for investment capital in the industry remains unmet $^{184}$, which would be necessary in order to create employment for the population.

- Therefore, considerable foreign borrowing was inevitable ${ }^{185}$ for the industry, which was at least successful for the large-scale industry. In 1927 alone, 2 million new, permanent jobs had been created, and the reinstatement of another 2 million people was made possible as a result of the supply of new major capital, especially from foreign sources to large-scale industry. ${ }^{186}$ The unemployment rate increased sharply as investors from abroad withdrew their loans.

- The medium ${ }^{187}$ and small industry hardly had this opportunity to raise funds via the stock market, due to the current prospectus

to the study by Edgar Lawrence Smith, Common Stocks as long-term Investments, New York 1926, which "statistically for the period from 1860-1921 has shown that, on average, even shares offer greater security and have dropped a higher annuity than fixed-income stocks (in the United States, that is, a relatively stable currency). This rule applies even if the shares have been bought in the worst year, i.e. bought at the highest prices and sold at the lowest prices.

182 Cp. Rittershausen, H. (1929), p. 50.

183 Cp. Rittershausen, H. (1929), p. 51.

184 Cp. Rittershausen, H. (1929), p. 57, quoted from Polak, N. J. (1926), pp. 24-25.

185 Cp. Voth, H.-J. (1994), p. 68.

186 Cp. Rittershausen, H. (1929), p. 83.

187 The medium-sized industry included companies from 201 to 5,000 workers, and in 1925, in addition to the 4,005,900 persons, many family members were employed, so that the number of employees, including family members, would certainly exceed 10 million (cp. Rittershausen, H. (1929), p. 82, Preliminary Results of the 1925 Business Census in Economics and Statistics, 1928, p. 48.) 
regulations. ${ }^{188}$ With adequate access to capital, it would have been possible to relieve the labor market by more than one million people. ${ }^{189}$ In the same period of time - under unspeakable sacrifices - industry, trade and commerce have managed to reach new levels of profitability and full competitiveness on the world market. ${ }^{190}$

- The manipulation of the capital market leads to a high foreign debt and also leads to the employment of foreign industries and workers instead of domestic ones. ${ }^{191}$

- Furthermore, industry has been disadvantaged by numerous tax and other regulations in the race for capital, e. g. the stamp duty on securities $(2 \%)$ was four times higher on industrial bonds that of covered bonds and government bonds, and industrial bonds were not eligible for use as collateral. ${ }^{192}$

Ultimately, the legislature was not aware of the scope of economic changes ${ }^{193}$, because the legislator continued to base the giltedged rule on the framework conditions of a pre-industrial society ${ }^{194}$ and could not see what effects such a partially compulsory economic system has and will have on the capital market. ${ }^{195}$

\section{VI CONCLUSION}

In the historical analysis of the development of foundations, it is stated that private commitment to the common good grows best

188 Cp. Rittershausen, H. (1929), pp. 82-84. Of the approximately 750 million corporate bonds newly issued domestically from 1924-1927, only 31.1 million (thirty-one!), that were 20 individual bonds, relate to such industrial firms whose equity was below 10 million Reichsmark, according to Zickerts Fondsanalysen 1927.

189 Cp. Rittershausen, H. (1929), p. 83.

190 Cp. Meakin, W. (1928).

191 Cp. Rittershausen, H. (1929), p. 50, p. 37.

192 Cp. Rittershausen, H. (1929), p. 61.

193 Cp. Rittershausen, H. (1929), p. 35.

194 Cp. Adam, T. (2009), p. 185.

195 Cp. Rittershausen, H. (1929), p. 9. 
where rulers stay out of it. ${ }^{196}$ Conversely, this means the more state interference, the less social capital.

This has proven true - as the article has shown - for charitable foundations in the gravest manner, and many lessons of the Austrian School of Economics and their theses on the role of the state have been confirmed.

Interventions by both the government and central bank are very dangerous for social capital. In the long run they did not reach their goal to safe social capital - but: In the long run social capital is dead, because interventions destroy it step by step.

The result was ultimately the same as with state intervention in the production: the foundations as owners of social capital remained only the empty name of the property (the worthless certificates of state and war bonds), the property itself entirely passed in the hands of the state, ${ }^{197}$ which disposed of its debts through currency reform at the expense of the creditors. Thus, social capital and ward money were only objects of exploitation for financial purposes of the state. ${ }^{198}$

\section{BIBLIOGRAPHY}

Adam T. (2009): Die volkswirtschaftliche Bedeutung von Stiftungen und "totem" Kapital, in: Stiftungen seit 1800, Kontinuitäten und Diskontinuitäten, Adam, T./ Frey, M./ Strachwitz, R. (Eds). Maecenata Schriften Band 3, Lucius \& Lucius, Stuttgart, 2009.

- (2015): Stiften und Stiftungen im deutsch-amerikanischen Vergleich von 1815 bis 1945, in: Reden, von S. (Ed.) Stiftungen zwischen Politik und Wirtschaft, pp. 23-50, Geschichte und Gegenwart im Dialog, Historische Zeitschrift / Beihefte N.F. 66, De Gruyter, Oldenbourg, Berlin, Boston 2015.

- (2015a): Wissenschaftsförderung im Deutschen Kaiserreich, in: Hoffmann, D./ Kolboske, B./ Renn, J. (Eds.) „Dem Anwenden muss das Erkennen vorausgehen," pp. 195-218, Max Planck Research

\footnotetext{
196 Cp. Adloff F. (2010), p. 292.

197 Cp. Mises, L. (1932/2007), p. 31.

198 Cp. Rittershausen, H. (1929), pp. 43-44.
} 
Library for the History and Development of Knowledge (Ed.), Edition Open Access, Berlin, 2015.

- (2016): „Der Anteil der Staatsanleihen an der Finanzierung staatlicher Haushalte. Eine vergleichende Studie der staatlichen Defizitfinanzierung in den USA und Deutschland vom ausgehenden 18. bis in das frühe 20. Jahrhundert." in: Bouvier, B./ Kruke, A./ Kufferath, P./ Lenger, F./ Planert, U./ Süß, D./ Woyke, M./ Ziemann, B. (Eds.) Archiv für Sozialgeschichte 56 (2016), pp. 219-247.

- (2018): Zivilgesellschaft oder starker Staat? Das Stiftungswesen in Deutschland 1815-1989, Campus, Frankfurt, New York 2018.

Adam, T. / Lingelbach, G. (2013): “The Place of Foundations and Endowments in German History: A Historical-Statistical Approach." Nonprofit and Voluntary Sector Quarterly, 44 (2) March 2013, pp. 223-247.

Adloff, F. (2010): Philantrophisches Handeln - Eine historische Soziologie des Stiftens in Deutschland und den USA, Campus Verlag, Frankfurt, New York, 2010.

- (2014): Philanthropisches Handeln den USA und Deutschland, in: Lauterbach, W./ Hartmann, M./ Ströing, M. (Eds.), Reichtum, Philanthropie und Zivilgesellschaft, Springer, Wiesbaden 2014.

Ahamed, L. (2016): Die Herren des Geldes. Wie vier Herren die Weltwirtschaftskrise auslösten und die Welt in den Bankrott trieben, 3. Auflage, FinanzBuch Verlag, München, 2016.

Aldcroft, D. (1978): Die zwanziger Jahre, Geschichte der Weltwirtschaft im 20. Jahrhundert, Band 3, München, 1978.

Amadeo, K. (2018): US GDP by Year Compared to Recessions and Events. The Strange Ups and Downs of the U.S. Economy Since 1929, https://www.thebalance.com/us-gdp-by-year-3305543, downloaded on 30.12.2018.

Anderson, B. (1949): Economics and the Public Welfare, 2nd Ed. Liberty Press, Indianapolis, 1979.

Anheier, H. (2003): Das Stiftungswesen in Deutschland: Eine Bestandsaufnahme in Zahlen, in: Bertelsmann-Stiftung, (Ed.) Handbuch Stiftungen: Ziele - Projekte - Management - Rechtliche Grundlagen, Gabler, 2. Auflage, Wiesbaden, 2003.

Anheier H./ Appel A. (2004): „,Stiftungen in der Bürgergesellschaft: Grundlegende Fragen zu Möglichkeiten und Grenzen", in: Aus Politik und Zeitgeschichte, B14, 2004, pp. 8-15. 
Anon. (1926): „Kirche und Aufwertung“ in Seiler, L. (ed.) Das Evangelische Rheinland, Essen, Jan. 1926 III, 1, p. 17. https://www. archiv-ekir.de/images/PDF/DasEvangelischeRheinland/ DasEvRheinland1926.pdf, downloaded on 25.8.2018.

Bagus,P./ Marquard, A. (2014): Warum andere auf Ihre Kosten immer reicher werden, FinanzBuch Verlag, München, 2014.

Baumstark, E. (1833): Staatswissenschaftliche Versuche über Staatskredit, Staatsschulden und Staatspapiere, Reichard, Heidelberg, 1833.

Bayerisches Landesamt für Statistik und Datenverarbeitung (2008): 200 Jahre amtliche Statistik in Bayern 1808-2008, https://www. statistik.bayern.de/mam/ueber_uns/geschichte/festschrift200jahre_teil1.pdf, downloaded on 25.8.2018.

Biedermann, W. (2011): Struktur der Finanzierung von Instituten der Kaiser-Wilhelm-Gesellschaft zur Förderung der Wissenschaften e.V. (1924-1944), epubli, Berlin, 2011.

Blankart, C. (2017): Öffentliche Finanzen in der Demokratie, Eine Einführung in die Finanzwissenschaft, 9. Auflage, Vahlen, München, 2017.

Bresciani-Turroni, C. (2007): Economics of Inflation: A Study of Currency Depreciation in Post-War Germany, Ludwig von Mises Institute, Auburn, (Ed.) Alabama, 2007.

Bruckmüller, E. (2004): Putzger - Historischer Weltatlas, 103. Auflage, Cornelsen Verlag, Berlin, 2004.

Bundesverband Deutscher Stiftungen (2008): Verzeichnis Deutscher Stiftungen, 1. Band: Zahlen, Daten, Fakten zum deutschen Stiftungswesen, Berlin, 6. Auflage 2008, https://katalog.ub.uni-heidelberg.de/cgi-bin/titel.cgi?katkey=66861025, downloaded on 28.8.2018.

- (2014): Zahlen, Daten, Fakten 2014, https://issuu.com/bundesverband/docs/zdf_ebook_final_webgr____e, downloaded on 28.8.2018.

— (2018): Stiftungserrichtungen 1990-2017, https://www.stiftungen. org/de/stiftungen/zahlen-und-daten/grafiken-zum-download. html, downloaded on 28.8.2018.

Camphausen, A. von. (2003): Geschichte des Stiftungswesens, Bertelsmann Stiftung (Ed.): Handbuch Stiftungen: Ziele - Projekte Management - Rechtliche Gestaltung, 3. Auflage, Gabler, Wiesbaden, 2003. 
Crafts, N. (2004): "Regional GDP in Britain, 1871-1911: “Some Estimates," Working Paper 03/04, London School of Economics, p. 10.

Deutsche Reichsbank (1925): Die Reichsbank 1901-1925, Druckerei der Reichsbank, Berlin, 1925.

Landsburgh, A. (1924): „Die Politik der Reichsbank und die Reichsschatzanweisungen nach dem Kriege," Schriften des Vereins für Sozialpolitik, Duncker \& Humblot, Leipzig 1924.

Deutscher Reichstag (1923): Reichstagsprotokolle: 366. Sitzung am 15.6.1923, pp. 11381-11407, https://www.reichstagsprotokolle.de/ Blatt2_w1_bsb00000044_00404.html, downloaded on 7.10.2018.

— (1923): Reichstagsprotokolle: 367. Sitzung am 16.6.1923: Erste, zweite und dritte Beratung über das Gesetz zur Anlage von Mündelgeld, $\S 1807$ und § 1811 BGB, https://www.reichstagsprotokolle.de/ Blatt2_w1_bsb00000044_00440.html, https://www.reichstagsprotokolle.de/Blatt2_w1_bsb00000044_00438.html, https://www. reichstagsprotokolle.de/Blatt2_w1_bsb00000062_00568.html, downloaded on 7.10.2018.

Cholet, J. (1988): Der Etat des Deutschen Reiches in der Bismarckzeit, Berliner Wissenschaftsverlag, Berlin, 1988.

Döpfner, M. (2011): Die Freiheitsfalle, Propyläen Verlag, Berlin, 2011. Flierl, R. (2009): "Crack-up-Boom," in: Smart Investor, Ausgabe 4/2009, pp. 44-46.

FAZ (2013): Die Deutschen Staatsschulden seit 1850, http://www. faz.net/aktuell/wirtschaft/staatsfinanzen-der-deutscheschuldenberg-ist-auf-dauer-untragbar-12188759.html, downloaded on 1.8.2018.

Gielen, G. (1994): Können Aktienkurse noch steigen? Langfristige Trendanalyse des deutschen Aktienmarktes, Gabler, Wiesbaden, 1994.

Glismann, H./ Horn, E.-J. (1998): A Funded System of Social Security: Design and Implications, in: Morath, K. (Ed.): Verläßliche soziale Sicherung, Frankfurter Institut Stiftung Marktwirtschaft und Politik, Bad Homburg, 1998.

Hacker, M. (2013): Gibt es "Gerechtigkeit" in der Steuerpolitik?, Inauguraldissertation an der Freien Universität Berlin, Stuttgart/Berlin, 2013. https://refubium.fu-berlin.de/bitstream/ handle/fub188/5924/Dissertation_Mark_Hacker.pdf?sequence $=1 \&$ is Allowed $=\mathrm{y}$, downloaded on 25.7.2018. 
Häussler, F. (2018): Von Kriegsanleihen und Sammlungen, Augsburger Allgemeine Online, 5.4.2018, https://www.augsburger-allgemeine.de/augsburg/Von-Kriegsanleihen-und-Sammlungenid50797236.html, downloaded on 21.10.2018.

Haffert, L. (2015): Die schwarze Null: Über die Schattenseiten ausgeglichener Haushalte, eBook, Suhrkamp Verlag, Berlin, 2016.

Havenstein, R. (1923): Protokoll der Sitzung des Zentralausschusses der Reichsbank vom 25. August 1923, in: Bundesarchiv (Hrsg.), Bl. 244f., Akten der Reichskanzlei. Weimarer Republik - Die Kabinette Stresemann I/II / Band 1 / Dokumente / Nr. 24, pp. 101-125, http://www.bundesarchiv.de/ aktenreichskanzlei/1919-1933/0000/str/str1p/kap1_2/para2_ 24.html, downloaded on 28.10.2018.

Hayek, F. (1954/2003): History and Politics, in: Hayek, F. (Ed.): Capitalism and the Historians, reprinted 2003, Routledge, London, 2003.

- (1988/1992): The Fatal Conceit - The Errors of Socialism, edited by Bartley, (1988), reprinted 1992, Routledge, London, 1992.

Hecht, F. (1874): Die Rheinische Hypothekenbank in Mannheim, 3. Auflage, Schneider, Mannheim, 1874.

- (1875): Die Mündel- und Stiftungsgelder in den deutschen Staaten, Cota, Stuttgart, 1875.

- (1892): Die ländlichen Darlehen der Rheinischen Hypotheken-Bank in Mannheim, Mitteilungen aus der Praxis, Hahn, Mannheim, 1892.

- (1902): Die Mannheimer Banken 1870 bis 1900: Beiträge zur praktischen Bankpolitik, Duncker \& Humblot, Leipzig, 1902.

- (1908): Die Organisation des Bodenkredits in Deutschland, Dritte Abteilung, Erster Band, Duncker \& Humbolt, Leipzig, 1908.

Helfferich, K. (1915): Speech in the Deutschen Reichstag on 10.3.1915, Reichstagsprotokolle, 1. Sitzung, https://www.reichstagsprotokolle.de/Blatt_k13_bsb00003402_00045.html, downloaded on 20.10.2018.

- (1915a): Speech in the Deutschen Reichstag on 20.8.1915, Reichstagsprotokolle, 14. Sitzung, https://www.reichstagsprotokolle.de/Blatt_k13_bsb00003402_00236.html, downloaded on 20.10.2018.

Henning, F.-W. (1988): Das industrialisierte Deutschland 1914 bis 1986, 6. ergänzte Aufl., UTP Schöningh Verlag, Paderborn, 1988. 
Herold, J. (1985): The Reichsbank and Public Finance in Germany 19241933. Knapp, Frankfurt a. Main, 1985.

Hettlage R. (1971): Die Wirtschaft zwischen Zwang und Freiheit, Wirtschaftsplanung und Weltanschauung, Nauwelaerts Verlag, Löwen, 1971.

Hirschfelder, H./ Nutzinger, W. (2006): Das Kaiserreich 1871-1914, 2. Auflage, Buchner, Bamberg, 2006.

Hoffmann, W./ Müller, J. (1959): Das Deutsche Volkseinkommen 18511957, in: Hoffmann, W. (Ed.): Schriften zur angewandten Wirtschaftsforschung, Tübingen, Mohr, 1959, p. 20 in Verbindung mit Statistisches Jahrbuch für das Deutsche Reich, 58. Jahrgang, 1939/40, p. 578, (für die Jahre 1913-1936), Daten entnommen aus: GESIS Datenarchiv, Köln. histat. Studiennummer 8224, Datenfile Version 1.0.0, https://histat.gesis.org/histat/de/table/details/6EA3E5F69BAC6472689CB4F98E9CFB, downloaded on 26.12.2018.

Hoffmann W. (1965): Das Wachstum der deutschen Wirtschaft seit der Mitte des 19. Jahrhunderts, Springer, Berlin 1965.

Holtfrerich, C.-L. (1986): The German Inflation 1914-1923: Causes and Effects in International Perspective, De Gruyter, Berlin, New York, 1986.

Horn, T. (2014): Mittelständische Kreditinstitute in Kriegszeiten, Inauguraldissertation, Johann-Wolfgang-Goethe-Universität, Frankfurt am Main, https://d-nb.info/1066731101/34, downloaded on 21.10.2018.

Hülsmann, J. (2014): Krise der Inflationskultur, 2. Auflage, FinanzBuch Verlag, München, 2014.

Huerta de Soto, J. (2012): Money, Bank Credit and Economic Cycles, 3rd Edition, Ludwig von Mises Institute, Auburn, 2012.

Kiehling, H. (1998): „Der Funktionsverlust der deutschen Finanzmärkte in Weltkrieg und Inflation 1914-1923." Jahrbuch für Wirtschaftsgeschichte / Economic History Yearbook, 39 (1), pp. 11-58.

Kiesinger, K. G. (1968): Bericht der Bundesregierung über die Untersuchung der Wettbewerbsverschiebungen im Kreditgewerbe und über eine Einlagensicherung, Drucksache V/3500, http://dipbt.bundestag.de/doc/btd/05/035/0503500.pdf, downloaded on 21.10.2018.

Kipp, T. (1923): „Mündelsicherheit,“ in: Gruchots Beiträgen: Erläuterung des deutschen Rechts, 1923, 3. Jahrg., 5/6, pp. 497-514. 
Kocka, J. (2004): „Die Rolle der Stiftungen in der Bürgergesellschaft der Zukunft,“ in: Bundeszentrale für politische Bildung (ed.), Aus Politik und Zeitgeschichte, Beilage zur Wochenzeitschrift Das Parlament, B 14/2004, Frankfurt, pp. 3-7.

Königreich Bayern (1806): Die Anlegung von Pupillen-, Kirchenund Stiftungsgelder bei der Bank zu Fürth, Verordnung von 21. November 1806.

Köppe, H. (1906): „Ist die Wertzuwachssteuer überwälzbar?“ in: Schanz, G. (ed.) Finanz-Archiv, Zeitschrift für das gesamte Finanzwesen, 23. Jahrgang, Cott, Stuttgart, Berlin, 1906, pp. 1-12.

Kraus, E. (2001): „Aus Tradition modern.“ Zur Geschichte von Stiftungswesen und Mäzenatentum in Deutschland im 19. und 20. Jahrhundert, in: Historisches Jahrbuch, 121 (2001), pp. 400-420. - (2012): Stiftungen (19./20. Jahrhundert), in: Historisches Lexikon Bayerns, http://www.historisches-lexikon-bayerns.de/Lexikon/Stiftungen.

Kremling, A. (2014): „Interventionismus und Modelle“, in: Kriterion - Journal of Philosophy (2014) 28, pp. 98-115.

Leisering, L. (2005): „Das deutsche Sozialmodell — woher, wohin?“ In: Soziologische Revue, Band 28, Heft 3, pp. 197-208.

Martin, P. (2016): Deutsche Hyperinflation 1923 - Das Trauma; Düsseldorfer Studien, Düsseldorf, 2016.

McCarthy, K. (2003): American Creed: Philanthropy and the Rise of Civil Society 1700-1865, University of Chicago Press, 2003.

Meakin, W. (1928): The New Industrial Revolution, A Study for the General Reader of Rationalization and Post-War Tendencies of Capitalism and Labour, Gollancz, London, 1928.

Metz, R. (2015): Volkswirtschaftliche Gesamtrechnungen, in: Thomas Rahlf (Ed.), Deutschland in Daten, Zeitreihen zur Historischen Statistik, Bonn 2015, pp. 189-190.

Mises, L. (1929/2013): Kritik des Interventionismus, Akston, München, 2013.

- (1932/2007): Die Gemeinwirtschaft — Untersuchungen über den Sozialismus, unveränderter Nachdruck der 2. Auflage von 1932, Lucius \& Lucius, Stuttgart, 2007.

- (1940/1989): Interventionism: An Economic Analysis, Bien Greaves, B. (Ed.), The Foundation for Economic Education, Inc., Irvington, Hudson, New York, 1989. 
- (1976): Kritik des Interventionismus - Verstaatlichung des Kredits?, Wissenschaftliche Buchgesellschaft, Darmstadt, 1976.

- (2008): Human Action, The Scholar's Edition, Ludwig von Mises Institute, Auburn, 2008.

Monopolkommission (2014): Auszug aus Hauptgutachten XX (2012/2013), Kapitel VI Wettbewerb auf den Finanzmärkten, https://www.monopolkommission.de/images/PDF/HG/ HG20/6_Kap_HG20.pdf.

Polak, N. J. (1926): Grundzüge der Finanzierung mit Rücksicht auf die Kreditdauer, Spaeth \& Linde, Wien, Berlin 1926.

Preußisches Staatsministerium (2000/1842): Protokolle des Preußischen Staatsministeriums 1817-1934/38, Berlin-Brandenburgische Akademie der Wissenschaften (Eds.) Band 3, Olms-Weidmann, Hildesheim, Zürich, 2000, p. 99-100, file://C:/Users/Petra\%20 $\operatorname{Tr} \% \mathrm{C} 3 \% \mathrm{~A} 4 \mathrm{~g} /$ Downloads/27WUvsuf0JVCM.pdf, downloaded on 30.9.2018.

- (2001/1842): Protokolle des Preußischen Staatsministeriums 18171934/38, Berlin-Brandenburgische Akademie der Wissenschaften (Eds.) Band 9, Olms-Weidmann, Hildesheim, Zürich, 2001, p. 120-124, p. 177. http://preussenprotokolle.bbaw.de/bilder/ Band\%209.pdf, downloaded on 14.10.2108.

Rahlf, T. (Ed.) (2015): Deutschland in Daten. Zeitreihen zur Historischen Statistik, Bundeszentrale für politische Bildung, Bonn, http://www.bpb.de/shop/buecher/zeitbilder/211002/ deutschland-in-daten, downloaded on 2.8.2018.

Ramb, B.-T. (2014): Interventionismus, in Gabler Wirtschaftslexikon, Springer Gabler Verlag (Herausgeber), Gabler Wirtschaftslexikon, online im Internet: http://wirtschaftslexikon.gabler.de/Archiv/ 2125/interventionismus-v7.html, downloaded on 10.8.2014.

Reichstagsprotokolle (1923): Verabschiedung des Gesetzes zur Änderung der Mündelsicherheit, https://www.reichstagsprotokolle.de/Blatt2_w1_bsb00000044_00438.html.

- (1923a): Gesetz vom 23.6.1923 und Begründung, https://www. reichstagsprotokolle.de/Blatt2_w1_bsb00000062_00568.html.

Ritschl, A./ Spoerer, M. (1997): „Das Bruttosozialprodukt in Deutschland nach den amtlichen Volkseinkommens- und Sozialproduktsstatistiken 1901-1995," Economic History Yearbook, 1997, vol. 38, issue 2, pp. 27-54. 
Ritter, G. (1981): Das Deutsche Kaiserreich 1871-1914, 4. Auflage, Vandenhoeck und Ruprecht, Göttingen, 1981.

- (2010): Der Sozialstaat - Entstehung und Entwicklung im internationalen Vergleich, 3. Auflage Oldenbourg Verlag, München, 2010.

Rittershausen, H. (1929): Die Reform der Mündelsicherheitsbestimmungen und der industrielle Anlagekredit — Zugleich ein Beitrag zum Erwerbslosenproblem, Fischer Verlag, Jena, 1929.

Roesler, K. (1967): „Die Finanzpolitik des Deutschen Reiches im Ersten Weltkrieg," in: Schriften des Instituts für das Spar-, Giro- und Kreditwesen an der Universität Bonn, Band 37, Berlin 1967, pp. 37-38. Roser, M./ Ortiz-Ospina, E. (2018): “Public Spending”, OECD (Ed.), published online at OurWorldInData.org, https://ourworldindata.org/public-spending, downloaded on 1.11.2018.

Rothbard, M. (2009 [1962]): Man, Economy, and State, Ludwig von Mises Institute (Ed.), Scholar's Edition, second Edition, Auburn, 2009.

Savigny, F. (1840): System des heutigen römischen Rechts, 2. Band, Veit \& Comp., Berlin, 1840.

Scheller, B. (2004): Memoria an der Zeitenwende: Die Stiftungen Jakob Fuggers des Reichen vor und während der Reformation, Akademie Verlag, Berlin, 2004.

Schumpeter, J. (2008): Das Wesen des Geldes, Mann, F. (Ed.), Vandenhoeck \& Ruprecht, Göttingen, 2008.

Spoerer, M./ Streb, J. (2013): Neue deutsche Wirtschaftsgeschichte des 20. Jahrhunderts, Oldenburg Verlag, München, 2013.

Stadt Wunsiedel (o. J.): Die Hospitalstiftung 1449, https://wunsiedel.de/de/rathaus/stiftungen/\#c62, downloaded on 3.10.2018. Statista (2018): Statistiken zum Bruttoinlandsprodukt (BIP) und Wirtschaftswachstum, https://de.statista.com/themen/26/bip/, downloaded on 30.12.2018.

Strachwitz, von R. (2010): Die Stiftung - ein Paradox? Zur Legitimität von Stiftungen, Stiftungen in einer politischen Ordnung, Lucius \& Lucius, Stuttgart, 2010.

Statistisches Bundesamt (1972): Bevölkerung und Wirtschaft 18721972, Kohlhammer, Stuttgart und Mainz, 1972.

Strachwitz, R. von (2017): „Das Stiftungswesen Soziale Bewegung, Finanzierungsinstrument der Zivilgesellschaft oder Störfaktor 
der Demokratie?“ In: Forschungsjournal Soziale Bewegungen. Jg. 4, 2017, pp. 30-34.

Thünen, J. (1844): „Beiträge zur Kritik des Entwurfs der Vormundschaftsverordnung" veröffentlicht in: Jeverländische Nachrichten, Band 3, Nr. 24 vom 14. Juni 1846, pp. 157-161.

Universitätsarchiv München (1911): Bestand I (Stipendien), I-III-29 (v. Lamontsches Stipendium), maschinenschriftliche Aktennotiz ad 1368/11 aus dem Jahre 1911 (angeheftet an den Brief des Verwaltungsausschusses der Ludwig-Maximilians-Universität an den Akademischen Senat der König-Ludwig-Maximilians-Universität vom 15. April 1911).

Vetter, A./ Remer-Bollow.U. (2017): Bürger und Beteiligung in der Demokratie, Springer, Wiesbaden, 2017.

Watrin, C. (1998): Vom Kapitalismus zum Wohlfahrtsstaat und zurück?, in: Knappe, E./ Berthold, N. (Eds.) Ökonomische Theorie der Sozialpolitik: Bernhard Külp zum 65. Geburtstag, Springer, Berlin, Heidelberg, 1998.

Zickert, H. (1927): „Einleitung zu Fondsanalysen 1927,“ Wirtschaftlicher Ratgeber, Berlin 1927. 
